\title{
Genes targeted by the estrogen and progesterone receptors in the human endometrial cell lines HECIA and RL95-2 Karin Tamm* ${ }^{* 1,2}$, Miia Rõõm ${ }^{\dagger 1}$, Andres Salumets $2,3,4,5$ and Madis Metsis ${ }^{1,5}$
}

\begin{abstract}
Address: ${ }^{1}$ Centre for Biology of Integrated Systems, Tallinn University of Technology, Tallinn, Estonia, ${ }^{2}$ Nova Vita Clinic, Centre for infertility treatment and medical genetics, Tallinn, Estonia, ${ }^{3}$ Department of Obstetrics and Gynecology, University of Tartu, Tartu, Estonia, ${ }^{4}$ Department of Biotechnology, Institute of Molecular and Cell Biology, University of Tartu, Tartu, Estonia and ${ }^{5}$ Competence Centre on Reproductive Medicine and Biology, Tallinn, Estonia
\end{abstract}

Email: Karin Tamm* - karin.tamm@mail.ee; Miia Rõõm - miia.room@ttu.ee; Andres Salumets - asalumets@novavita.ee; Madis Metsis - madis.metsis@ttu.ee

* Corresponding author †Equal contributors

Published: 24 December 2009

Reproductive Biology and Endocrinology 2009, 7:150 doi:10.1/86/1477-7827-7-150

This article is available from: http://www.rbej.com/content/7/I//50

(C) 2009 Tamm et al; licensee BioMed Central Ltd.

This is an Open Access article distributed under the terms of the Creative Commons Attribution License (http://creativecommons.org/licenses/by/2.0), which permits unrestricted use, distribution, and reproduction in any medium, provided the original work is properly cited.
Received: 9 October 2009

Accepted: 24 December 2009

\begin{abstract}
Background: When the steroid hormones estrogen and progesterone bind to nuclear receptors, they have transcriptional impact on target genes in the human endometrium. These transcriptional changes have a critical function in preparing the endometrium for embryo implantation.

Methods: 382 genes were selected, differentially expressed in the receptive endometrium, to study their responsiveness of estrogen and progesterone. The endometrial cell lines HECIA and RL95-2 were used as experimental models for the non-receptive and receptive endometrium, respectively. Putative targets for activated steroid hormone receptors were investigated by chromatin immunoprecipitation (ChIP) using receptor-specific antibodies. Promoter occupancy of the selected genes by steroid receptors was detected in ChIP-purified DNA by quantitative PCR (qPCR). Expression analysis by reverse transcriptase (RT)-PCR was used to further investigate hormone dependent mRNA expression regulation of a subset of genes.

Results: ChIP-qPCR analysis demonstrated that each steroid hormone receptor had distinct group of target genes in the endometrial cell lines. After estradiol treatment, expression of estrogen receptor target genes predominated in HECIA cells $(n=137)$ compared to RL95-2 cells $(n=35)$. In contrast, expression of progesterone receptor target genes was higher in RL95-2 cells $(n=83)$ than in HECIA cells $(n=7)$ after progesterone treatment. RT-PCR analysis of 20 genes demonstrated transcriptional changes after estradiol or progesterone treatment of the cell lines.

Conclusions: Combined results from ChIP-qPCR and RT-PCR analysis showed different patterns of steroid hormone receptor occupancy at target genes, corresponding to activation or suppression of gene expression after hormone treatment of HECIA and RL95-2 cell lines.
\end{abstract}

\section{Background}

The human endometrium is a dynamic tissue that undergoes cyclic changes in preparation for endometrial receptivity and embryo implantation. Endometrial development consists of proliferative and secretory phases, and the two major regulators of this process are the ovarian steroid hormones $17 \beta$-estradiol (E2) and progesterone ( $\mathrm{P} 4)$. In the proliferative phase, estrogens stim- 
ulate the proliferation of the epithelial and stromal components of the endometrium, while in the secretory phase P4 is involved in glandular differentiation and inhibition of E2-mediated cell proliferation [1]. In the absence of implantation, declining levels of P4 and E2 signal the degeneration of the endometrial tissue, which is followed by regeneration during the next cycle.

The biological activities of E2 and P4 are mediated mainly by nuclear receptors (NRs). Binding of a steroid hormone to its cognate receptor results in a conformational change in the NR that allows the ligand-NR complex to bind with high affinity to response elements in DNA and regulate transcription of target genes. Two types of E2 receptors, ER $\alpha$ and ER $\beta$, encoded by separate genes, are found in humans $[2,3]$. Although ER $\alpha$ and ER $\beta$ are present in all endometrial cell types over the entire menstrual cycle, they are expressed at higher levels during the proliferative phase and show lower activity during the secretory phase because of the suppressive effect of P4 [4].

P4 signalling is also mediated by two receptors, PRA and PRB [5], which are encoded by the same gene but transcribed from different promoters, resulting in a PRB that has an additional 164 amino acids at the N-terminus [6]. PRB is a stronger transcriptional activator in most cell types, while PRA acts often as a dominant negative repressor for PRB activity $[7,8]$. PRA and PRB levels are similar during the proliferative phase. In the early secretory phase, PRA is dominant, while higher PRB levels during the mid-secretory phase have been described [9]. The expression of the PR gene in endometrial glands is controlled by E2 and P4, where E2 induces PR synthesis and $\mathrm{P} 4$ down-regulates the expression of its own receptor [1].

Implantation of the developing embryo involves a molecular dialogue between the endometrium and blastocyst that involves a number of specific mediators including membrane receptors, components of the extra-cellular matrix, growth factors, cytokines and lipid components of the cell membranes [10]. The endometrium is receptive for embryo attachment only during a restricted period called the "implantation window" (IW). In humans, the IW is limited to days 20-24 of the menstrual cycle and is achieved through the coordinated action of P4 and E2. Thus, an imbalance of steroid hormone levels and their ratios could influence the regulation of target genes, leading to female infertility by disturbing endometrial receptivity during the IW.

Microarray technology has led to genome-wide identification of gene expression pathways involved in implantation events. Based on five transcriptome studies [11-15], we selected 382 genes with different expression levels during the IW in human endometrium. The aim of this study was to investigate whether these pre-selected genes could be directly regulated by E2 and P4 through their specific receptors. To achieve the purpose, to study hormone dependent receptivity of the endometrium, we used two human uterine epithelial cell lines as in vitro models.

HEC1A was used as a model of non-receptive endometrium, and RL95-2 was used as a model of receptive endometrium [16-19]. The cell lines were chosen based on earlier studies which have demonstrated that RL95-2 cells have stronger adhesiveness for human JAR choriocarcinoma multicellular spheroids compared to HEC1A cells [20-22] and are thus considered as a model of the receptive endometrium. Following hormone treatment of the cells, binding of steroid hormone receptors to the promoters of selected genes was investigated by chromatin immunoprecipitation (ChIP) with specific antibodies, and detection of the isolated genomic sequences with quantitative PCR (qPCR). E2- and P4-dependent gene regulation was confirmed for 20 genes by reverse transcriptase (RT)-PCR.

\section{Methods}

\section{Endometrial cell culture}

HEC1A (\#HTB-112, American Type Culture Collection, ATCC, Teddington, UK) cells were grown in McCoy 5A medium (\#A1324, AppliChem GmbH, Darmstadt, Germany), while RL95-2 (\#CRL-1671, ATCC) cells were maintained in DMEM/F12 (AppliChem GmbH) medium with $10 \mathrm{mM}$ Hepes and $5 \mu \mathrm{l} / \mathrm{ml}$ insulin. Both media were supplemented with $2 \mathrm{~g} / \mathrm{L}$ sodium bicarbonate (AppliChem $\mathrm{GmbH}$ ), 10\% fetal bovine serum (FBS) (AppliChem $\mathrm{GmbH}$ ) and $1 \%$ penicillin/streptomycin (AppliChem $\mathrm{GmbH}$ ). Both studied cell lines express E2 and $\mathrm{P} 4$ specific nuclear receptors (ER $\alpha, \mathrm{ER} \beta, \mathrm{PRA}, \mathrm{PRB})$ as indicated by the ATCC. For hormonal treatment, E2 (Sigma-Aldrich, Helsinki, Finland) or P4 (4-Pregnene3,20-dione, Sigma-Aldrich) was added to the culture media to a final concentration of $10^{-8} \mathrm{M}$ as described before $[23,24]$. For cultures with hormone supplements, dextran-coated charcoal-treated FBS and media without phenol red were used for $48 \mathrm{~h}$ prior to experiments to adapt similar conditions and avoid possible hormonelike (estrogenic) activity of Phenol red. Hormone treatment was $45 \mathrm{~min}$ for ChIP experiments and $3 \mathrm{~h}, 6 \mathrm{~h}$ or 12 $\mathrm{h}$ for mRNA experiments.

\section{Chromatin immunoprecipitation}

Chromatin was immunoprecipitated as previously described [25], using following antibodies: monoclonal mouse anti-human ER $\alpha$ antibody (D-12, sc-8005); polyclonal rabbit anti-human ER $\beta$ antibody (H-150, sc-8974); monoclonal mouse anti-human PRAB antibody (AB-52, sc-810) that recognizes both human PRA and PRB receptors (AB-52, sc-810); and monoclonal mouse anti-human 
PRB antibody (B-30, sc-811) that recognizes only the additional NH2-terminal stretch of PRB receptor (Santa Cruz Biotech, CA, USA). Preliminary experiments determined an optimal formaldehyde cross-linking time of 15 min for both cell lines. Chromatin was fragmented to an average size of 0.5 - $2 \mathrm{~kb}$ using a Vibra-Cell ultrasonic processor (Sonics, Newtown, CT USA). Antibody-antigen complexes were precipitated with GammaBind ${ }^{\mathrm{TM}}$ plus Sepharose $^{\mathrm{TM}}$ (GE Healthcare Life Sciences, Uppsala, Sweden), eluted with hot $0.1 \%$ SDS and uncrosslinked overnight at $65^{\circ} \mathrm{C}$ in the presence of Protein $\mathrm{K}$ (SigmaAldrich). DNA was purified using a Gel Extraction Kit (Qiagen, Helsinki, Finland). Control experiments used preimmune total IgG (Cell Signalling Technology, Inc, Danvers, MA, USA) to estimate the non-specific binding by unspecific antibodies.

\section{ChIP-qPCR for detection of genomic sequences}

Specific genomic regions in the ChIP DNA samples were detected by qPCR. The 382 genomic targets for PCR were selected from previously published endometrial tissue microarray data (See additional file 1) [11-15] using two criteria: (i) $\geq 2$-fold up- or down-regulated mRNA expression during IW and (ii) evolutionary conservation of human and murine orthologous sequences. Primers were designed to detect and amplify a region from +1000 to 5000 bp from the transcription start site using the Primer3 program [26] detecting NR involvement in formation of the basal transcription complex. All primers were designed to have a melting temperature (Tm) of $60^{\circ} \mathrm{C}$. Primer specificity was controlled using the alignment algorithms BLAT/iPCR [27] and BLAST [28] to search the whole human genome. Primers were obtained from MWG Biotech (Edsberg, Germany). PCR was performed using HotStarTaq Master Mix (Qiagen) with $0.05 \mathrm{ng}$ of template DNA and 1.25 pmol of primers for each reaction, according to the manufacturer's instructions.

PCR products were detected by qPCR using 384-well plates and a SYBR green detection method with an ABI HT7900 RT-PCR machine (Applied Biosystems, Foster City, CA, USA). PCR conditions were: HotStarTaq DNA Polymerase activation step for $14.5 \mathrm{~min}$ at $95^{\circ} \mathrm{C}, 40$ cycles of denaturation for $30 \mathrm{~s}$ at $95^{\circ} \mathrm{C}$, annealing for $45 \mathrm{~s}$ at $58^{\circ} \mathrm{C}$ and extension for $45 \mathrm{~s}$ at $72^{\circ} \mathrm{C}$. A dissociation step was added to confirm the purity of PCR products by melting-curve analysis with $5 \mathrm{~min}$ ramping from $60^{\circ} \mathrm{C}$ to $95^{\circ} \mathrm{C}$.

\section{RT-PCR}

RNA was extracted using an RNeasy Mini Kit (Qiagen). Cells were washed once with phosphate-buffered saline prior to extraction, lysed directly in the tissue culture dish and homogenized by 10 strokes with an insulin syringe. RNA was prepared according to the manufacturer's proto- col. Genes ( $\mathrm{n}=20$, ADAMDEC1, CD86, ETV1, FLT1, FOXA2, GRIP1, HES1, HOXA1, IHH, KLK3, MEF2D, MMP7, NCOA1, OTOF, PLXNA2, RELB, SMARCA2, TBX19, TNC, and ZNF54) were chosen for RT-PCR analysis based on positive ChIP experiment results, focusing mostly on transcription factors (See additional file 2). For mRNA analysis, $5 \mu \mathrm{g}$ of total RNA was subjected to reverse transcription, using SuperScript ${ }^{\circledR}$ III First-Strand Synthesis SuperMix (\#18080-400, Invitrogen Life Technologies, Carlsbad, CA, USA), as described by the manufacturer. GAPDH specific primers were used to normalize the cDNA synthesis with forward and reverse primers CTCTCTGCTCCTCCTGTTCGAC and TGAGCGATGTGGCTCGGCT, respectively. cDNA specific primer pairs were designed using Primer3 software and tested for unspecific priming against human genomic and mRNA sequences using iPCR software (MWG Biotech). Primers were designed to generate amplicons of 75-150 bp with a Tm of $60^{\circ} \mathrm{C}$. PCR conditions for reverse transcriptase products were as described above with the exception of a $15 \mathrm{~s}$ annealing step at $58^{\circ} \mathrm{C}$, and a $30 \mathrm{~s}$ extension time to account for the shorter PCR products.

\section{RT-PCR data analysis}

Quantitative qPCR results were analysed using the publicly available software Miner [29]. Outliers were excluded manually when the mean coefficient of variation $(\mathrm{CV})$ for CT (cycle threshold) for triplicates was $>1 \%$. Expression values for all transcripts were normalized to the endogenous control of GAPDH, and ratios relative to nontreated samples were generated. Relative gene expression ratios were calculated according to GED (Gene Expression Difference) by CT protocol [30], using the average efficiency of each gene and the CT of each triplicate. To compare the effects of hormone treatments on HEC1A and RL95-2 cell lines, statistical analysis was performed on $\log 2$-transformed values of gene expression ratios using an unpaired Student's t-test at a 95\% confidence level.

\section{Annotation of genes}

Gene classifications were carried out using the PANTHER (Protein Analysis THrough Evolutionary Relationships), [31] classification system that specifies genes by functions based on published evidence and evolutionary relationships that predict gene function in the absence of direct experimental evidence. Clustering analysis was performed with the Cluster 3.0 program [32], using uncentered correlation and complete centroid linkage. Inverted CT (CTinv) values were used for clustering qPCR data. The baseline was set to 40 and CTinv was calculated as CTinv $=40$-Ct. Visualisation of clustering data was done using Java TreeView software.

Gene annotation, sequence information, gene descriptions and accession numbers (IDs) were downloaded 
from BioMart [33] NCBI [34] and UCSC genome browser [35] databases. All datasets were imported and kept in a database supported by MySQL database management software [36].

\section{Results \\ E2- and P4-receptor target genes in HECIA and RL95-2 cells}

Two endometrial cell lines, HEC1A and RL95-2, were used to investigate the steroid hormone-dependent binding of NRs to the promoters of 382 IW-specific genes (See additional file 1). Although the native receptive endometrium is under the combined influence of both E2 and P4, we performed hormonal treatments separately to reveal E2 or P4 dependent action through their specific nuclear receptors. Cells were treated with either E2 or P4 followed by ChIP using antibodies against the steroid hormone receptors: ER $\alpha$, ER $\beta$, PRB, or PRAB (which recognizes both PRA and PRB receptors). Quantitative qPCR with specific primers was used to detect NR-binding to the promoter region of the selected genes. HEC1A cells were treated with E2 to simulate the non-receptive-like endometrium and with P4 for comparing P4 effects on the two endometrial cell lines. Out of 382 investigated genes, 137 were ER targets: 101 were bound by ER $\alpha, 96$ were bound by ER $\beta$, and 60 were targets of both receptors (Figure $1 \mathrm{~A}$ ). When the targets common to both ERs $(n=56)$ and the targets shared by ERs and PRs $(n=7)$ were excluded, 40 genes were found to be exclusively regulated by ER $\alpha$ and 34 genes by ER $\beta$ (Table 1).

The amino acid sequence of the progesterone receptor PRA is contained within the sequence of PRB, so producing antibodies specific to PRA is not feasible. Therefore, PRA target genes were found by subtracting anti-PRB targets from the common pool of all PRAB-targets as PRB and PRAB overlapping target genes were considered to be PRB-specific. Seven target genes for P4-mediated action in HEC1A cells were identified, 5 for PRA and 2 for PRB (Figure 1A). All PR targets overlapped with ER targets and thus they were not considered to be unique targets for $\mathrm{P} 4$ action in HEC1A cells (Table 2).

The RL95-2 cell line was used as a model for the receptive endometrium with E2 and P4 treatments performed separately. ChIP-qPCR analysis revealed four distinct groups of target genes for each steroid hormone receptor $(E R \alpha$, ER $\beta$, PRA, and PRB) in RL95-2 cells (Figure 1B). After P4 treatment, anti-PR antibodies recognized chromatin from 83 out of the 382 potential target genes; anti PRB for 40 and anti-PRAB for 52, including overlapping targets for two antibodies. After removing common targets between PRs and ERs and subtracting anti-PRB targets from the common pool of all PRAB-targets, 37 genes were considered to be unique targets for PRA and 8 for PRB (Table 3 ).
Although PRAB antibody should detect both PRA and PRB receptor subtypes, 31 genes were targeted solely by PRB and not identified by PRAB antibody. Twenty-five of them were found to be PRB specific, while six were additionally co-regulated by at least one of the ERs. These 25 unique PRB targets were also regarded as PRB-specific, thus resulting in 33 unique PRB target genes (Table 3). E2 treatment of RL95-2 cells resulted in 35 genes bound by ERs, where in total 17 loci were immunoprecipitated by ER $\alpha$ and 24 by ER $\beta$ antibody (Figure 1B), including overlapping targets for two antibodies. After deducted common targets, we discovered nine unique target genes for ER $\alpha$, eight for ER $\beta$ (Table 4), and five common targets for both ERs (data not shown).

The total number of genes targeted after E2 treatment of HEC1A and RL95-2 cells is shown in Figure 1. Approximately four times as many genes were bound by ERs in HEC1A cells than in RL95-2 cells, which had 137 and 35 target genes, respectively. These results confirmed that HEC1A is a better model of the non-receptive endometrium with $\mathrm{E} 2$ exerting its primary role in tissue proliferation. In contrast, $\mathrm{P} 4$ treatment resulted in 10 times more PR targets in RL95-2 cells $(n=83)$ than in HEC1A cells $(n=7)$, supporting the view of RL95-2 cell line as a model for the receptive endometrium with $\mathrm{P} 4$ preparing the endometrium for embryo nidation.

\section{E2- and P4-mediated mRNA expression in HECIA and RL95-2 cell lines}

To elucidate the biological significance of the molecular interactions seen by ChIP, we complemented the initial results with mRNA expression studies for 20 genes (See additional file 2). All selected genes were detected as NR targets by ChIP-qPCR and half $(\mathrm{n}=10)$ of them were classified as transcription factors. The other criteria after transcription factors was to find genes which has not been described as an ER or PR targets before.

HEC1A and RL95-2 cells were treated with E2 or P4 for 3, 6 , or $12 \mathrm{~h}$. At least 2-fold up- or down-regulation of mRNA expression levels were detected for 12 genes (CD86, FOXA2, IHH, MEF2D, MMP7, NCOA1, OTOF, PLXNA2, RELB, SMARCA2, TNC, and ZNF549) out of 20 genes studied (Table 5). Although, the activities of transcription factor coding genes GRIP1 and TBX19 changed significantly during the hormonal treatments, these alterations remained below the 2-fold threshold. cDNA amplification was not observed for 6 genes ADAMDEC1, ETV1, FLT1, HES1, HOXA1 and KLK3 in either cell line regardless of hormonal treatment (data not shown). Surprisingly, the observed changes in E2- or P4-dependent mRNA expression occasionally conflicted with the ChIPqPCR results. For example, although the secreted growth factor Indian hedgehog $(I H H)$ and otoferlin (OTOF) were 
Table I: List of unique target genes for ER $\alpha$ and ER $\beta$ in HECIA cell line after E2 treatment

\begin{tabular}{|c|c|c|c|}
\hline \multirow{2}{*}{\multicolumn{2}{|c|}{$\begin{array}{l}\text { Gene symbol* Gene name } \\
\text { Unique targets for } E R \alpha\end{array}$}} & \multirow{2}{*}{\multicolumn{2}{|c|}{ Unique targets for $\operatorname{ER} \beta$}} \\
\hline & & & \\
\hline$A B C B \mid O$ & ATP-binding cassette, subfamily $B$, member 10 & $A Q P 3$ & Aquaporin 3 \\
\hline ADCYAPI & Adenylate cyclase-activating polypeptide I & B3GAT3 & Beta-I,3-glucuronyltransferase 3 \\
\hline AGL & Amylo-I,6-glucosidase, 4-alpha- glucanotransferase & $B M P I O$ & Bone morphogenetic protein 10 \\
\hline APRT & Adenine phosphoribosyltransferase & $C L U$ & Clusterin \\
\hline ARID5B & AT-rich interaction domain-containing protein 5B & COG5 & Component of oligomeric golgi complex 5 \\
\hline C3orfl & Chromosome 3 open reading frame 1 & CRSP9 & Mediator complex subunit 7 \\
\hline CCLII & Chemokine, CC motif, ligand II & $D M B T I$ & Deleted in malignant brain tumors I \\
\hline CCL7 & Chemokine, CC motif, ligand 7 & DNAH9 & Dynein, axonemal, heavy chain 9 \\
\hline CCT6B & $\begin{array}{l}\text { Chaperonin-containing T-complex polypeptide I, } \\
\text { subunit } 6 \mathrm{~B}\end{array}$ & $\mathrm{FECH}$ & Protoporphyria, erythropoietic \\
\hline CD86 & Cd86 antigen & FENI & FLAP structure-specific endonuclease I \\
\hline CEACAM3 & $\begin{array}{l}\text { Carcinoembryonic antigen-related cell adhesion } \\
\text { molecule } 3\end{array}$ & FYB & FYN-binding protein \\
\hline CLDN4 & Claudin 4 & GBAS & Glioblastoma amplified sequence \\
\hline ECMI & Extracellular matrix protein I & GPX3 & Glutathione peroxidase 3 \\
\hline EDN3 & Endothelin 3 & GRIPI & Glutamate receptor-interacting protein I \\
\hline FBLN2 & Fibulin 2 & $H B B$ & Hemoglobin--beta locus \\
\hline FOSLI & FOS-like antigen I & KIAA0427 & KIAA0427 \\
\hline GRIKI & Glutamate receptor, ionotropic, kainate I & LGTN & Ligatin \\
\hline GSN & Gelsolin & MEF2D & Myocyte enhancer factor 2D \\
\hline HOXAI & Homeobox Al & NINJI & Nerve injury-induced protein I \\
\hline ITGB7 & Integrin, beta-7 & PDGFA & Platelet-derived growth factor, alpha polypeptide \\
\hline ITPA & Inosine triphosphatase & PENK & Proenkephalin \\
\hline LGALS8 & Lectin, galactoside-binding, soluble, 8 & PLXNB3 & Plexin B3 \\
\hline$M B$ & Myoglobin & PRODH & Proline dehydrogenase \\
\hline NEK6 & Never in mitosis gene a-related kinase 6 & SC65 & Synaptonemal complex protein SC65 \\
\hline NID2 & Nidogen 2 & SERPINDI & Heparin cofactor II \\
\hline ODF2 & Outer dense fiber of sperm tails 2 & SLCI6A4 & $\begin{array}{l}\text { Solute carrier family } 16 \text { (monocarboxylic acid transporter), } \\
\text { member } 4\end{array}$ \\
\hline POFUTI & Protein o-fucosyltransferase I & TDG & Thymine-DNA glycosylase \\
\hline PWPI & PWPI homolog (S. Cerevisiae) & TFDPI & Transcription factor DPI \\
\hline RELB & $\begin{array}{l}\text { v-rel avian reticuloendotheliosis viral oncogene } \\
\text { homolog b }\end{array}$ & TGM2 & Transglutaminase 2 \\
\hline SEC6IB & SEC6I complex, beta subunit & TNC & Tenascin C \\
\hline SFRSI 6 & Splicing factor, arginine/serine- rich 16 & TNFRSFIOC & Tumor necrosis factor receptor superfamily, member $10 c$ \\
\hline$S G C B$ & Sarcoglycan, beta & TP63 & Tumor protein $\mathrm{p} 63$ \\
\hline SPARC & Secreted protein, acidic, cysteine-rich & TRIPIO & Thyroid hormone receptor interactor 10 \\
\hline SPATA2 & Spermatogenesis-associated protein 2 & WFDC2 & WAP four-disulfide core domain 2 \\
\hline SSFA2 & Sperm-specific antigen 2 & & \\
\hline TFAP2C & Transcription factor AP2-gamma & & \\
\hline$T R H$ & Thyrotropin-releasing hormone deficiency & & \\
\hline TRIMI6 & Tripartite motif-containing protein 16 & & \\
\hline WNT5A & $\begin{array}{l}\text { Wingless-type MMTV integration } \\
\text { site family, } \\
\text { member } 5 \mathrm{~A}\end{array}$ & & \\
\hline$x C L 2$ & Chemokine, $\mathrm{C}$ motif, ligand 2 & & \\
\hline
\end{tabular}

(*) Official gene symbol by HUGO Gene Nomenclature Committee (HGNC).

detected as E2-ER targets in HEC1A cells, E2-induced mRNA expression was observed in RL95-2 cells but not in HEC1A cells.

From the selected 20 genes five genes showed significant cell line-specific mRNA expression either in HEC1A or RL95-2 cell line (Table 5, in bold). IHH expression was detected in RL95-2 cell line-specific manner until $6 \mathrm{~h}$ after $\mathrm{E} 2$ treatment or $3 \mathrm{~h}$ after $\mathrm{P} 4$ treatment, but was down-reg- ulated after longer hormonal exposure. In addition to $I H H$, the expression of three other genes: plexin A2 (PLXNA2), OTOF and a SWI/SNF related family member (SMARCA2) were induced by E2 or P4 in the RL95-2 cell line. In HEC1A cells, on the contrary, the expression of matrix metalloprotease 7 (MMP7) was detected in nontreated HEC1A cells and was gradually down-regulated after treatments by both hormones. 
A. HEC1A cell line

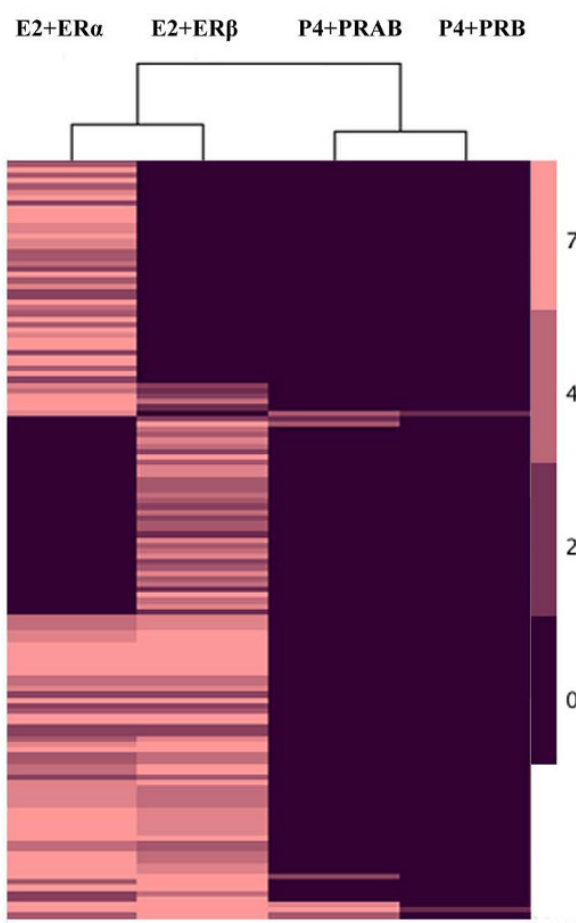

B. RL95-2 cell line

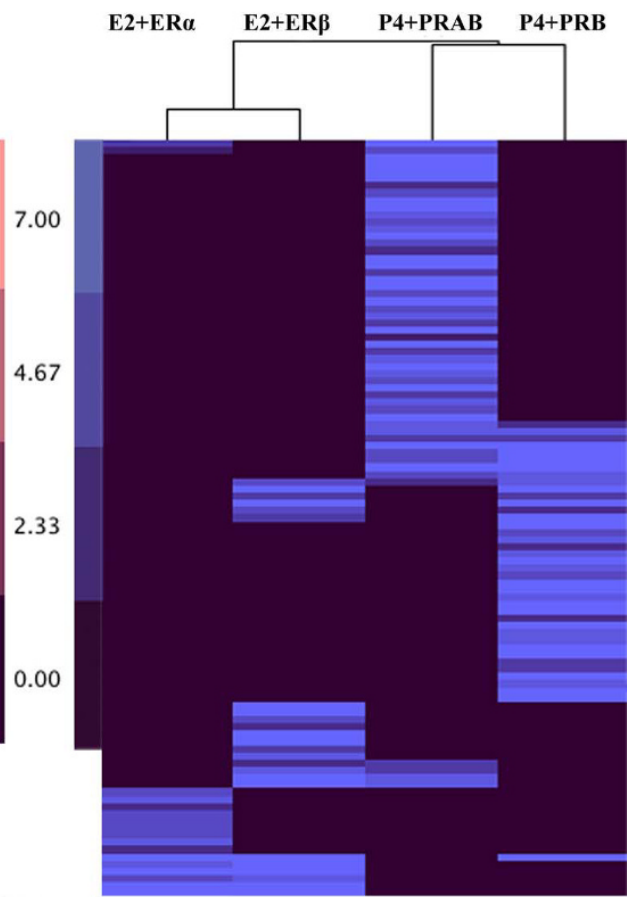

Figure I

Cluster analysis of ER $\alpha$, ER $\beta$, PRAB, PRB target genes in HECIA and RL95-2 cells after E2 or P4 treatment. Target genes revealed from ChIP-qPCR experiment were clustered with Cluster 3.0 program and visualized using Java TreeView software. A. HECIA cell line. E2+ER $\alpha$ : I0I ER $\alpha$ target genes after E2 treatment; E2+ER $\beta$ : 96 ER $\beta$ target genes after E2 treatment; P4+PRAB: 7 PRAB target genes after P4 treatment; and P4+PRB: 2 PRB target genes after P4 treatment. B. RL952 cell line. E2+ER $\alpha$ : 17 ER $\alpha$ target genes after E2 treatment; E2+ER $\beta$ : 24 . ER $\beta$ target genes after E2 treatment; P4+PRAB: 52 PRAB target genes after P4 treatment; and P4+PRB: 40 PRB target genes after P4 treatment.

Analysis of gene expression in HEC1A and RL95-2 cell lines showed almost opposite responses to E2 and P4. A significant difference $(\mathrm{p}<0.05)$ in transcript levels was observed between the two cell lines in the expression of nine genes after E2 treatment (Figure 2). Furthermore, CD86, FOXA2, GRIP1, NCOA1, RELB, TBX19, TNC, and

Table 2: List of PRA and PRB target genes in HECIA cell line after P4 treatment

\begin{tabular}{ll}
\hline Gene symbol* & Gene name \\
\hline $\begin{array}{l}\text { Targets for PRA } \\
\text { CD28 }\end{array}$ & CD28 molecule \\
COL5A2 & Collagen, type V, alpha-2 \\
ETS2 & V-Ets avian erythroblastosis virus \\
& e26 oncogene homolog 2 \\
MYST4 & Histone acetyltransferase MYST4 \\
OTOF & Otoferlin \\
Targets for PRB & \\
TCF4 & Transcription factor 4 \\
ZNFI67 & Zinc finger protein 167
\end{tabular}

(*) Official gene symbol by HUGO Gene Nomenclature Committee (HGNC).
ZNF549 genes showed opposite regulation in the two cell lines, with mRNA levels up-regulated in RL95-2 cells but down-regulated in HEC1A cells after E2 treatment when compared to non-treated samples (Figure 2). The expression of MEF2D was also significantly different between the cell lines, but unlike the other genes, it was up-regulated by E2 in both cell lines. P4 similarly exerted opposite effects on gene expression in the two endometrial cell lines as mRNA levels of the three transcription factor genes FOXA2, NCOA1, TBX19, and extracellular matrix tenascin-C $(T N C)$ gene were significantly $(\mathrm{p}<0.05$, Figure 3) up-regulated in RL95-2 cells and down-regulated in HEC1A cells post P4 treatment.

\section{Discussion}

The exact molecular characteristics of the embryo impantation are still not completely characterised because of the complexity of using human embryos and endometrial tissue in reseach, therefore other means must be elucidated for research of receptivity of the endometrium. Used RL95-2 and HEC1A cell lines are both described as endometrial epithelial cell lines derived from adenocarcinoma cells. Our interest to investigate the suitability of 
Table 3: List of unique target genes for PRA and PRB in RL95-2 cell line after P4 treatment

\begin{tabular}{|c|c|c|c|}
\hline \multirow{2}{*}{\multicolumn{2}{|c|}{$\begin{array}{l}\text { Gene symbol* Gene name } \\
\text { Unique targets for PRA }\end{array}$}} & \multirow{2}{*}{\multicolumn{2}{|c|}{ Unique targets for PRB }} \\
\hline & & & \\
\hline APRT & Adenine phosphoribosyltransferase & ARID5B & AT rich interactive domain 5B (MRFI-like) \\
\hline BNIPI & $\begin{array}{l}\mathrm{Bc} \mid 2 / \text { adenovirus EIB } 19-\mathrm{kD} \text { protein-interacting protein } \\
\mathrm{I}\end{array}$ & $A R L I$ & ADP-ribosylation factor-like I \\
\hline CCT6B & $\begin{array}{l}\text { Chaperonin-containing T-complex polypeptide I, } \\
\text { subunit 6B }\end{array}$ & $B R C A 2$ & Breast cancer 2 \\
\hline CLDN4 & Claudin 4 & C2orf3 & Chromosome 2 open reading frame 3 \\
\hline COL4A6 & Collagen, type IV, alpha-6 & CORT & Cortistatin \\
\hline DNAJBI & DNAJ/HSP40 homolog, subfamily b, member I & CROT & Carnitine O-octanoyltransferase \\
\hline ECMI & Extracellular matrix protein I & EIF3I & Eukaryotic translation initiation factor 3 , subunit I \\
\hline EXTI & Exostosin I & ETVI & ETS variant gene I \\
\hline EXTL2 & Exostosin-like 2 & $F G F / 2$ & Fibroblast growth factor 12 \\
\hline FGF9 & Fibroblast growth factor 9 & GADD45A & $\begin{array}{l}\text { Growth arrest- and DNA damage-inducible gene } \\
\text { GADD45, alpha }\end{array}$ \\
\hline FLTI & Fms-related tyrosine kinase I & GATA2 & GATA-binding protein 2 \\
\hline GPLD & Phospholipase DI, glycosylphosphatidylinositol-specific & GTF2F2 & General transcription factor IIf, polypeptide 2, 30-kD \\
\hline IFNAR2 & Interferon, alpha, beta, and omega, receptor 2 & HESI & Hairy and enhancer of split I homolog \\
\hline ITGAIO & Integrin, alpha-10 & $\mathrm{IHH}$ & Indian hedgehog \\
\hline ITGA2 & Integrin, alpha-2 & KLK3 & Kallikrein-related peptidase 3 \\
\hline ITGB7 & Integrin, beta-7 & MEF2D & Myocyte enhancer factor 2D \\
\hline KIAA0427 & KIAA0427 & NCR3 & Natural cytotoxicity triggering receptor 3 \\
\hline$\angle A M B I$ & Laminin, beta-I & NFI & Neurofibromatosis, type I \\
\hline MAOA & Monoamine oxidase $\mathrm{A}$ & NFIX & Nuclear factor I/X (CCAAT-binding transcription factor) \\
\hline$M B$ & Myoglobin & NUP98 & Nucleoporin, 98-kD \\
\hline MYST4 & Histone acetyltransferase MYST4 & POSTN & Periostin \\
\hline NCOAI & Nuclear receptor coactivator I & PWPI & PWPI homolog (S. Cerevisiae) \\
\hline NCOR2 & Nuclear receptor corepressor 2 & RAD54L & Rad54, s. Cerevisiae, homolog-like \\
\hline NUPI55 & Nucleoporin, 155-kD & $R N F I 26$ & Ring finger protein 126 \\
\hline PDGFA & Platelet-derived growth factor, alpha polypeptide & SEMA3F & Semaphorin $3 \mathrm{~F}$ \\
\hline SLC29A2 & $\begin{array}{l}\text { Solute carrier family } 29 \text { (nucleoside transporter), } \\
\text { member } 2\end{array}$ & SNTGI & Syntrophin, gamma-I \\
\hline SOX4 & SRY-box 4 & SPATA2 & Spermatogenesis-associated protein 2 \\
\hline TGFA & Transforming growth factor, alpha & SPDEF & SAM pointed domain containing ets transcription factor \\
\hline TIALI & $\begin{array}{l}\text { Tia I cytotoxic granule-associated rna-binding protein- } \\
\text { like I }\end{array}$ & STCI & Stanniocalcin I \\
\hline TNC & Tenascin C & STIMI & Stromal interaction molecule I \\
\hline TRIPIO & Thyroid hormone receptor interactor 10 & TDRKH & Tudor and $\mathrm{KH}$ domains-containing protein \\
\hline TRMTI I & tRNA methyltransferase II homolog (S. Cerevisiae) & $T L X 2$ & T-cell leukemia, homeobox 2 \\
\hline UBE3C & Ubiquitin protein ligase $\mathrm{E} 3 \mathrm{C}$ & $U M O D$ & Uromodulin \\
\hline UBTF & $\begin{array}{l}\text { Upstream binding transcription factor } \\
\text { (RNA polymerase I) }\end{array}$ & & \\
\hline VEGFA & Vascular endothelial growth factor $A$ & & \\
\hline$X C L 2$ & Chemokine, $\mathrm{C}$ motif, ligand 2 & & \\
\hline ZNF549 & Zinc finger protein 549 & & \\
\hline
\end{tabular}

(*) Official gene symbol by HUGO Gene Nomenclature Committee (HGNC).

selected cell lines as an in vitro models of non-receptive and receptive endometrium was based on several studies published recently $[21,22,37,38]$. RL95-2 cell line has been characterized as a model of receptive endometrium by its ability to mimic relevant properties of the adhesion competent endometrial lining compared to HEC1A $[21,22]$.

The steroid hormones E2 and P4 bind to NRs to play a key role in preparing the endometrium for implantation of an embryo. NRs regulate transcription by binding to the proximal or distal regulatory regions of specific genes.
Transcriptional changes regulated by NRs have been suggested to involve chromosomal looping or PolII tracking that allows enhancers to interact with the transcription complex at the promoter [39]. In this study, we used ChIP-qPCR method to investigate whether genes previously identified as IW-specific become direct targets of NRs after hormonal treatment of endometrial cells.

Combining new technologies based on microarrays and high-throughput sequencing with the today's knowledge of entire human genome allows defining of all in vivo targets for transcription machinery in a single experiment 
Table 4: List of unique target genes for ER $\alpha$ and ER $\beta$ in RL95-2 cell line after E2 treatment

\begin{tabular}{|c|c|c|c|}
\hline \multirow{2}{*}{\multicolumn{2}{|c|}{$\begin{array}{l}\text { Gene symbol* Gene name } \\
\text { Unique targets for ER } \alpha\end{array}$}} & \multirow{2}{*}{\multicolumn{2}{|c|}{ Unique targets for $E R \beta$}} \\
\hline & & & \\
\hline ANXA2 & Annexin A2 & ETS2 & $\begin{array}{l}\text { v-ets avian erythroblastosis virus e } 26 \\
\text { oncogene homolog } 2\end{array}$ \\
\hline CHRNB2 & Cholinergic receptor, neuronal nicotinic, beta polypeptide 2 & FOXA2 & Forkhead box $\mathrm{A} 2$ \\
\hline COL3AI & Collagen, type III, alpha-I & MMP26 & Matrix metalloproteinase 26 \\
\hline GSN & Gelsolin & NINJI & Nerve injury-induced protein I \\
\hline RPS6KB2 & Ribosomal protein S6 kinase, 70-kD, 2 & SERPINDI & Heparin cofactor II \\
\hline SECTMI & Secreted and transmembrane I & SFRSI 6 & Splicing factor, arginine/serine-rich 16 \\
\hline SMARCA2 & $\begin{array}{l}\text { SWI/SNF related, matrix associated, actin dependent regulator of } \\
\text { chromatin, subfamily A, member } 2\end{array}$ & $T B X 19$ & T-box 19 \\
\hline SC65 & Synaptonemal complex protein SC65 & VDACl & Voltage-dependent anion channel I \\
\hline$V L D L R$ & Very low density lipoprotein receptor & & \\
\hline
\end{tabular}

(*) Official gene symbol by HUGO Gene Nomenclature Committee (HGNC).

Table 5: Genes $>2$ fold up- or down-regulated after hormone treatment in HECIA and/or RL95-2 cell line

\begin{tabular}{|c|c|c|c|c|c|}
\hline \multicolumn{3}{|c|}{ Up-regulation $>2$ fold } & \multicolumn{2}{|l|}{ ChIP target post E2 treatment } & \multirow[t]{2}{*}{ ChIP target post P4 treatment } \\
\hline HECIA & Molecular function* & E2 & & P4 & \\
\hline MEF2D & $\begin{array}{l}\text { Other transcription factor; Nucleic acid } \\
\text { binding }\end{array}$ & $6 \mathrm{~h}$ & HECIA ER $\beta$ & $3 \mathrm{~h}$ & RL95-2 PRB \\
\hline RL95-2 & & E2 & & P4 & \\
\hline CD86 & $\begin{array}{l}\text { Immunoglobulin receptor family member; } \\
\text { Membrane-bound signaling molecule; } \\
\text { Defense/immunity protein }\end{array}$ & $3 \mathrm{~h}$ & HECIA ER $\alpha$ & NS & ND \\
\hline MEF2D & $\begin{array}{l}\text { Other transcription factor; Nucleic acid } \\
\text { binding }\end{array}$ & $3 \mathrm{~h}$ & HECIA ER $\beta$ & $3 \mathrm{~h}$ & RL95-2 PRB \\
\hline OTOF & Otoferlin & $12 \mathrm{~h}$ & $\mathrm{HECIA}$ ER $\alpha$ and ER $\beta$ & $3 \mathrm{~h}$ & HECIA PRA \\
\hline PLXNA2 & $\begin{array}{l}\text { Tyrosine protein kinase receptor;Protein } \\
\text { kinase }\end{array}$ & $3 \mathrm{~h}$ & RL95-2 ER $\beta$ & $3 \mathrm{~h}$ & RL95-2 PRA \\
\hline RELB & Other transcription factor & $3 \mathrm{~h}$ & HECIA ER $\alpha$ & NS & ND \\
\hline SMARCA2 & DNA helicase & $3 \mathrm{~h}$ & RL95-2 ER $\alpha$ & $3 \mathrm{~h}$ & ND \\
\hline TNC & $\begin{array}{l}\text { Cell adhesion molecule; Extracellular matrix } \\
\text { glycoprotein }\end{array}$ & $3 \mathrm{~h}$ & HECIA ER $\beta$ & $3 \mathrm{~h}$ & RL95-2 PRA \\
\hline \multicolumn{6}{|c|}{ Down-regulation $>2$ fold } \\
\hline HECIA & Molecular function* & E2 & & P4 & \\
\hline CD86 & $\begin{array}{l}\text { Immunoglobulin receptor family member; } \\
\text { Membrane-bound signaling molecule; } \\
\text { Defense/immunity protein }\end{array}$ & $6 \mathrm{~h}$ & $\mathrm{HECIA} \mathrm{ER} \alpha$ & NS & ND \\
\hline FOXA2 & $\begin{array}{l}\text { Other transcription factor; Nucleic acid } \\
\text { binding }\end{array}$ & $3 \mathrm{~h}$ & RL95-2 ER $\beta$ & $12 \mathrm{~h}$ & ND \\
\hline MMP7 & Metalloprotease; Other extracellular matrix & $12 \mathrm{~h}$ & $\mathrm{HECIA} \mathrm{ER} \alpha$ and $\mathrm{ER} \beta$ & $12 \mathrm{~h}$ & ND \\
\hline NCOAI & Transcription factor; Acetyltransfer $\alpha$ se & $3 \mathrm{~h}$ & ND & $6 \mathrm{~h}$ & RL95-2 PRA \\
\hline$R E L B$ & Other transcription factor & $3 \mathrm{~h}$ & HECIA ER $\alpha$ & $6 \mathrm{~h}$ & ND \\
\hline TNC & $\begin{array}{l}\text { Cell adhesion molecule; Extracellular matrix } \\
\text { glycoprotein }\end{array}$ & $3 \mathrm{~h}$ & HECIA ER $\beta$ & $6 \mathrm{~h}$ & RL95-2 PRA \\
\hline ZNF549 & KRAB box transcription factor & & $\mathrm{HECIA} E R \alpha$ and $\mathrm{ER} \beta$ & $6 \mathrm{~h}$ & RL95-2 PRA \\
\hline RL95-2 & & E2 & & P4 & \\
\hline CD86 & $\begin{array}{l}\text { Immunoglobulin receptor family member; } \\
\text { Membrane-bound signaling molecule; } \\
\text { Defense/immunity protein }\end{array}$ & $12 \mathrm{~h}$ & HECIA ER $\alpha$ & NS & ND \\
\hline IHH & Other signaling molecule; Protease & $12 \mathrm{~h}$ & HECIA ER $\alpha / E R \beta$ & $6 \mathrm{~h}$ & RL95-2 PRB \\
\hline
\end{tabular}

(*) Molecular functions were obtained from PANTHER. In bold are genes with cell line-specific expression. NS: not significant gene expression, ND: not detected. Official gene symbols according to HUGO Gene Nomenclature Committee (HGNC). 


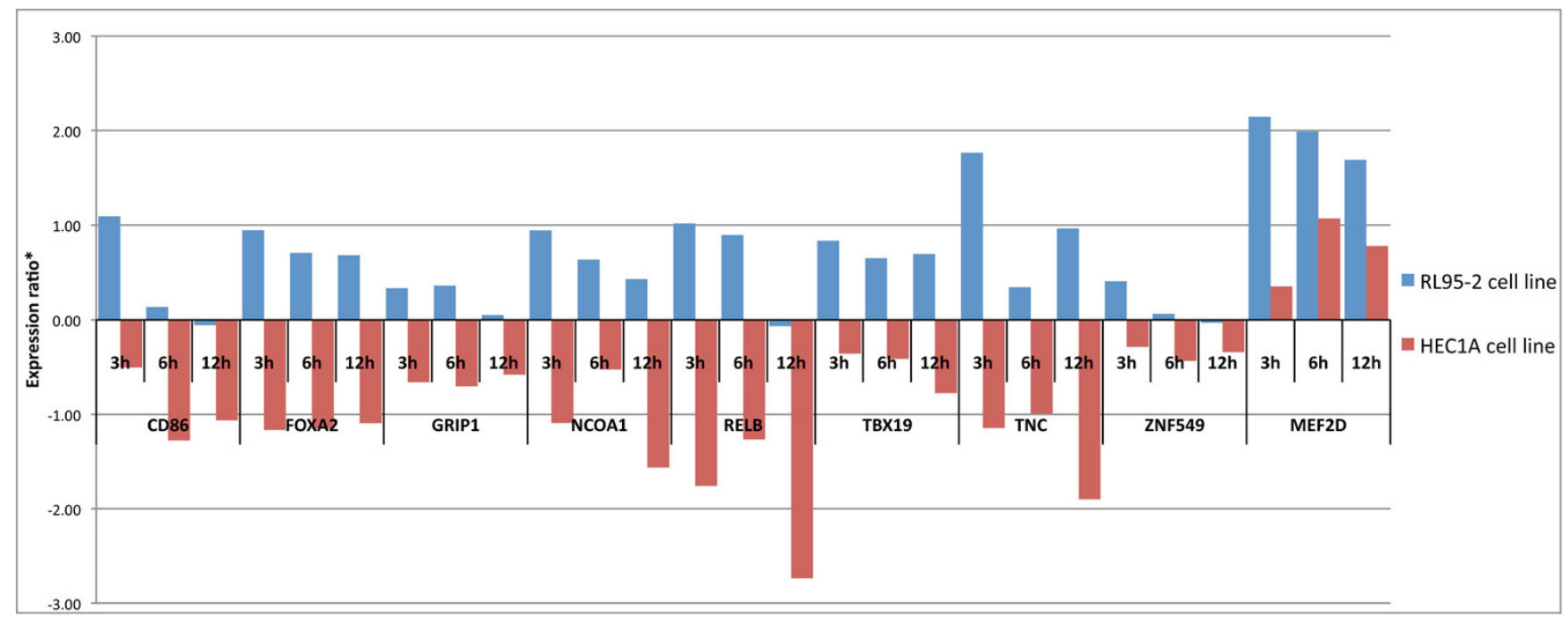

Figure 2

E2 mediated time-dependant gene expression in RL95-2 (blue) and HECIA (red) cell lines compared to nontreated samples. Expression profiles of CD86, FOXA2, GRIPI, NCOAI, RELB, TBXI9, TNC, ZNF549, and MEF2D genes had significant difference $(P<0.05$, two-tailed, unpaired Student's t-test with 95\% confidence of log2-transformed expression ratios relative to baseline expression) in mRNA expression ratios (*) between RL95-2 and HECIA cells after E2 treatment. E2 exposure predominantly induced mRNA level of gene expression in RL95-2 cells but down-regulated in HECIA cells (except for MEF2D gene).

$[23,24]$. Since NR activity is often tissue specific, we used primers specifically designed to detect the promoter regions of 382 genes known to exhibit differential expression in the human receptive endometrium. Our specific aim was to investigate whether the steroid hormone actions in endometrial cell lines HEC1A and RL95-2 sup- port their use as non-receptive and receptive endometrial models, respectively.

In non-receptive endometrium, the primary role of $\mathrm{E} 2$ is in tissue regeneration and proliferation. Analysis of the number of ER target genes identified by ChIP-qPCR after E2 treatment under our experimental conditions, revealed

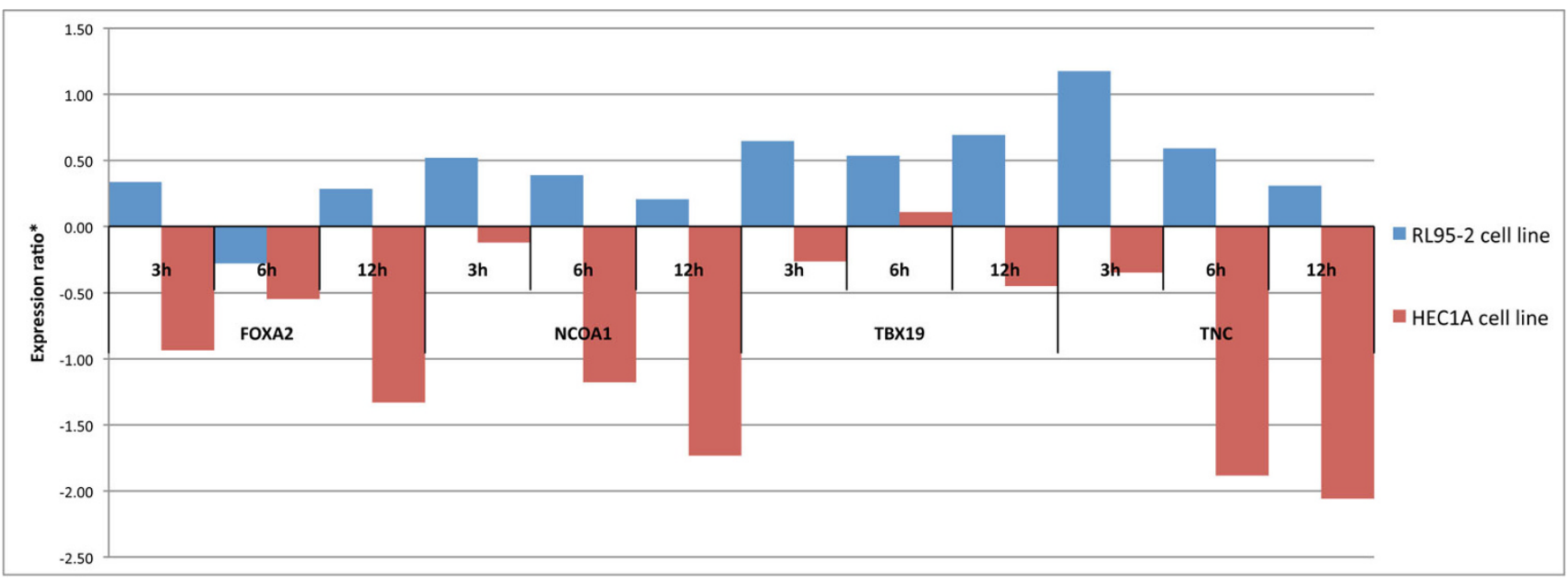

Figure 3

P4 mediated time-dependant gene expression in RL95-2 (blue) and HECIA (red) cell lines compared to nontreated samples. Expression profiles of FOXA2, NCOAI, TBX 19 and TNC genes had significant difference ( $P<0.05$, twotailed, unpaired Student's t-test with $95 \%$ confidence of log2-transformed expression ratios relative to baseline expression) in mRNA expression ratios (*) between RL95-2 and HECIA cells after P4 treatment. P4 mostly induced mRNA level in RL95-2 cells but down-regulated in HECIA cells. 
almost 4-fold difference between HEC1A $(n=137)$ and RL95-2 ( $\mathrm{n}=35)$ cells. This finding supports the idea of HEC1A as a good model for non-receptive endometrium being predominantly governed by E2 control. In addition to unique targets of ER $\alpha$ and ER $\beta$, we identified a subset of 60 genes in HEC1A cells and 5 genes in RL95-2 cells that were common for both ERs.

Previous in vitro studies have demonstrated that both homodimers $\mathrm{ER} \alpha / \mathrm{ER} \alpha$ or $\mathrm{ER} \beta / \mathrm{ER} \beta$ and heterodimers ER $\alpha / E R \beta$ can be formed when both ER subtypes are expressed in the same cell [40]. Moreover, it has been shown that in the absence of ER $\alpha, \operatorname{ER} \beta$ can either inhibit ER $\alpha$-mediated gene transcription or partly replace ER $\alpha$ as a transcription factor [41]. Thus, the common ER $\alpha$ and ER $\beta$ targets identified in this study could represent genes either activated by heterodimeric complexes or could reflect competitive binding of the two separate E2 receptors to the same regulatory element.

In receptive endometrium, the primary role of $\mathrm{P} 4$ is the preparation of the endometrium for embryo implantation. From our set of 382 genes, 83 were bound by PRs in RL95-2 cells, which was ten times more than in the HEC1A cell line $(n=7)$. Harduf and colleagues have demonstrated that there is a higher PRA/PRB ratio in RL95-2 cells compared to HEC1A cells indicating the possible important role of PRA during implantation window [22]. Even the both cell lines express E2 and P4 specific receptors (ATCC) the lack of specific antibody against PRA has made it difficult to compare the exact ratio levels of two PRs.

To investigate transcriptional changes that occur after NR binds to its promoter region, we assessed the expression of 20 selected genes. RT-PCR analysis showed that 12 out of selected 20 IW-specific genes had at least 2-fold up- or down-regulation in mRNA expression level after hormonal treatment. Five genes were expressed in cell line-specific manner as the expression of $I H H, P L X N A 2, O T O F$, and SMARCA2 was only observed in RL95-2 cells, while MMP7 activity was detected exclusively in HEC1A cells.

We included $I H H$ as a classical example of steroid hormone-dependent gene regulation during IW. Previous in vivo and in vitro studies revealed that the expression of $\mathrm{IHH}$ in the murine uterus is solely P4 dependent and essential for embryo implantation [42-44]. Our results showed that $I H H$ was the target gene for PRB after P4 treatment in RL95-2 cells. Indeed, RT-PCR analysis confirmed $\mathrm{IH} H$ expression only in RL95-2 cells. Interestingly, the mRNA levels of $I H H$ in RL95-2 cells were suppressed after the use of either E2 or P4 hormones (Table 5), differentially from murine uterus where $I H H$ expression depends only on P4 [42-44]. Yet, the recent work has indi- cated that the stromal not epithelial PR is critical for P4mediated induction of $\mathrm{IHH}$ expression in the mouse uterus [45]. Since the HEC1A and RL95-2 cell lines represent the epithelial cells of the endometrium, IHH expression in this endometrial compartment may be regulated by other hormonal mechanisms from internal tissue layers. Species difference between the estrous cycle of mice and the menstrual cycle in women is an additional factor to account for this discrepancy.

Our gene expression analysis focused mainly on transcription factors. Since the development and regeneration of endometrial tissue is largely governed by E2 and P4, a transcriptional regulatory feedback system is needed to mediate these dynamic and complex changes. The majority of E2-regulated genes are thought to be up-regulated after short (1-8 h) hormonal treatment, while most of the hormone-responsive genes are down-regulated after longer $(12-48 \mathrm{~h})$ treatment [39]. We examined the changes in mRNA expression following 3-12 h of hormonal exposure in order to investigate the rapid transcriptional changes caused by steroid hormones. We found that the increase of mRNA level in selected genes mainly occurred after short-term (3-6 h) treatment, while the majority of suppressive effects become visible after 6-12 h of treatment (Table 5, Figures 2 and 3).

Interestingly, when hormone responsiveness in two endometrial cell lines was compared, we found that hormonal treatments had almost opposite effects on gene expression. Treatments with E2 or P4 resulted in significant up- and down-regulation of genes in RL95-2 and HEC1A cells, respectively. Genes for the transcription factors FOXA2, NCOA1, TBX19, and the extracellular matrix glycoprotein $T N C$ had markedly different and opposite mRNA expression levels after E2 or P4 treatment in both of the cell lines investigated. All four genes were either down-regulated by both hormones in HEC1A or up-regulated in RL95-2 cells (Figures 2 and 3). In addition to already mentioned genes, E2 had also an inverse effect on CD86, GRIP1, RELB, and ZNF549 mRNA expression in the two endometrial cell lines, up-regulated in RL95-2 and down-regulated in HEC1A cells.

Some of the genes (ADAMDEC1, ETV1, FLT1, HES1, HOXA1 and KLK3) did not show any evidence of gene activity in both cell lines in spite of hormonal treatment. As all genes were selected from previous expression studies with human endometrium tissue samples the revealed effect could be cell line specific. In addition, we have to take into account that NR binding alone is not always sufficient to induce gene expression changes. The various combinations of transcription co-activators or -repressors are also required for proper gene activity, depending on the specific cell and tissue background [46-48]. In study- 
ing steroid hormone signalling, the non-genomic actions of steroid hormones in cross-talk between the growth factor receptors and cytoplasmic response must also be considered along with the direct transcriptional effects mediated by NRs $[49,50]$.

In present study we gained new information about the specific action of E2 and P4 during different stages of human endometrial development using a combination of ChIP-qPCR and RT-PCR. HEC1A and RL95-2 cell lines showed different sets of ER and PR target genes in response to hormonal stimuli as more target genes were detected for ERs in HEC1A cells than for PRs in RL95-2 cells. We also observed that hormone treatment had different impacts on gene expression levels in the two cell lines. The ChIP and RT-PCR results show that E2 and P4 actions in the human endometrium are more complex than the classic steroid hormone effects mediated through NRs.

\section{Conclusions}

The presented data demonstrates that the endometrial cell lines HEC1A and RL95-2 are suitable in vitro models for evaluating the effects of steroid hormones in non-receptive and receptive endometrium, respectively. This study deepens our understanding on the hormone responsive gene regulation during the cyclic changes in the human endometrium. However, further studies are needed to elucidate the complex mechanism by which endometrium acquires its receptivity.

\section{Competing interests}

The authors declare that they have no competing interests.

\section{Authors' contributions}

KT carried out experimental studies and prepared the draft version of the manuscript. MR participated in experimental work and performed data analysis of ChIP and mRNA expression studies. MM conceived the study, mainly designed and coordinated the work and performed the bioinformatic analysis. AS contributed to the design of the study and helped with the manuscript preparation. All authors read and approved the final version of the manuscript.

\section{Additional material}

\section{Additional file 1}

Supplementary Table 1. Genes used in ChIP-qPCR for ER and PR binding site analysis.

Click here for file

[http://www.biomedcentral.com/content/supplementary/14777827-7-150-S1.XLS]

\section{Additional file 2}

Suplementary Table 2. Genes used in mRNA analysis.

Click here for file

[http://www.biomedcentral.com/content/supplementary/14777827-7-150-S2.XLS]

\section{Acknowledgements}

This work has been supported by the Tallinn University of Technology (Targeted project no. B6II), Estonian Ministry of Education and Science (Targeted project no. SF0I80044s09) and Enterprise Estonia (Grant no. EU30200).

\section{References}

I. Graham RA, Seif MW, Aplin JD, Li TC, Cooke ID, Rogers AW, Dockery $\mathrm{P}$ : An endometrial factor in unexplained infertility. $\mathrm{Bmj}$ 1990, 300(6737):|428-|43|.

2. Enmark E, Pelto-Huikko M, Grandien K, Lagercrantz S, Lagercrantz J, Fried G, Nordenskjold M, Gustafsson JA: Human estrogen receptor beta-gene structure, chromosomal localization, and expression pattern. J Clin Endocrinol Metab 1997, 82( ( 2):4258-4265.

3. Kuiper GG, Gustafsson JA: The novel estrogen receptor-beta subtype: potential role in the cell- and promoter-specific actions of estrogens and anti-estrogens. FEBS Lett 1997. 4I 0(I):87-90.

4. Matsuzaki S, Fukaya T, Suzuki T, Murakami T, Sasano H, Yajima A: Oestrogen receptor alpha and beta mRNA expression in human endometrium throughout the menstrual cycle. Mol Hum Reprod 1999, 5(6):559-564

5. Wen DX, Xu YF, Mais DE, Goldman ME, McDonnell DP: The $\mathbf{A}$ and $B$ isoforms of the human progesterone receptor operate through distinct signaling pathways within target cells. Mol Cell Biol 1994, I 4(I 2):8356-8364.

6. Kastner P, Bocquel MT, Turcotte B, Garnier JM, Horwitz KB, Chambon $\mathrm{P}$, Gronemeyer $\mathrm{H}$ : Transient expression of human and chicken progesterone receptors does not support alternative translational initiation from a single mRNA as the mechanism generating two receptor isoforms. J Biol Chem 1990, 265(21):12163-12167.

7. Tung L, Mohamed MK, Hoeffler JP, Takimoto GS, Horwitz KB. Antagonist-occupied human progesterone B-receptors activate transcription without binding to progesterone response elements and are dominantly inhibited by A-receptors. Mol Endocrinol 1993, 7(10): I256-1265.

8. Vegeto E, Shahbaz MM, Wen DX, Goldman ME, O'Malley BW, McDonnell DP: Human progesterone receptor $A$ form is a cell- and promoter-specific repressor of human progesterone receptor B function. Mol Endocrinol 1993, 7(10): 1244-1255.

9. Arnett-Mansfield RL, DeFazio A, Mote PA, Clarke CL: Subnuclear distribution of progesterone receptors $A$ and $B$ in normal and malignant endometrium. J Clin Endocrinol Metab 2004, 89(3): 1429-1442.

10. Dimitriadis E, White CA, Jones RL, Salamonsen LA: Cytokines, chemokines and growth factors in endometrium related to implantation. Hum Reprod Update 2005, I I (6):613-630.

II. Kao LC, Tulac S, Lobo S, Imani B, Yang JP, Germeyer A, Osteen K, Taylor RN, Lessey BA, Giudice LC: Global gene profiling in human endometrium during the window of implantation. Endocrinology 2002, I43(6):2119-2138.

12. Krikun G, Schatz F, Taylor R, Critchley HO, Rogers PA, Huang J, Lockwood C): Endometrial endothelial cell steroid receptor expression and steroid effects on gene expression. J Clin Endocrinol Metab 2005, 90(3): $1812-1818$.

13. Mirkin S, Arslan M, Churikov D, Corica A, Diaz JI, Williams S, Bocca $S$, Oehninger S: In search of candidate genes critically expressed in the human endometrium during the window of implantation. Hum Reprod 2005, 20(8):2104-2117.

14. Punyadeera C, Dassen H, Klomp J, Dunselman G, Kamps R, Dijcks F, Ederveen A, de Goeij A, Groothuis P: Oestrogen-modulated 
gene expression in the human endometrium. Cell Mol Life Sci 2005, 62(2):239-250.

15. Carson: Changes in gene expression during the early to midluteal (receptive phase) transition in human endometrium detected by high-density microarray screening. Molecular Human Reproduction 2002, 8(No 9):87I-879.

16. Kuramoto H, Tamura S, Notake Y: Establishment of a cell line of human endometrial adenocarcinoma in vitro. Am J Obstet Gynecol 1972, I | 4(8): I012-1019.

17. Way DL, Grosso DS, Davis JR, Surwit EA, Christian CD: Characterization of a new human endometrial carcinoma (RL95-2) established in tissue culture. In Vitro 1983, 19(3 Pt I): 147-I58.

18. John NJ, Linke M, Denker HW: Retinoic acid decreases attachment of JAR choriocarcinoma spheroids to a human endometrial cell monolayer in vitro. Placenta 1993, 14(1): 13-24

19. Rohde LH, Carson DD: Heparin-like glycosaminoglycans participate in binding of a human trophoblastic cell line (JAR) to a human uterine epithelial cell line (RL95). J Cell Physiol 1993, I55(I): 185-196.

20. Thie M, Fuchs P, Butz S, Sieckmann F, Hoschutzky H, Kemler R, Denker HW: Adhesiveness of the apical surface of uterine epithelial cells: the role of junctional complex integrity. Eur J Cell Biol 1996, 70(3):22I-232.

21. Harduf H, Goldman S, Shalev E: Human uterine epithelial RL952 and HEC-IA cell-line adhesiveness: the role of plexin BI. Fertil Steril 2007, 87(6): 1419-1427.

22. Harduf H, Goldman S, Shalev E: Progesterone receptor A and cMet mediates spheroids-endometrium attachment. Reprod Biol Endocrinol 2009, 7:14.

23. Carroll JS, Brown M: Estrogen receptor target gene: an evolving concept. Mol Endocrinol 2006, 20(8): $1707-17 / 4$.

24. Lin CY, Vega VB, Thomsen JS, Zhang T, Kong SL, Xie M, Chiu KP Lipovich L, Barnett DH, Stossi F, et al:: Whole-genome cartography of estrogen receptor alpha binding sites. PLoS Genet 2007, 3(6): $\mathrm{e} 87$.

25. Weinmann AS: Novel ChIP-based strategies to uncover transcription factor target genes in the immune system. Nat Rev Immunol 2004, 4(5):38I-386.

26. Primer3 programm [http://frodo.wi.mit.edu/primer3/]

27. Kent WJ: BLAT--the BLAST-like alignment tool. Genome Res 2002, I 2(4):656-664.

28. Altschul SF, Madden TL, Schaffer AA, Zhang J, Zhang Z, Miller W, Lipman DJ: Gapped BLAST and PSI-BLAST: a new generation of protein database search programs. Nucleic Acids Res 1997, 25(17):3389-3402.

29. Miner software [http://www.miner.ewindup.info]

30. Schefe JH, Lehmann KE, Buschmann IR, Unger T, Funke-Kaiser H: Quantitative real-time RT-PCR data analysis: current concepts and the novel "gene expression's CT difference" formula. J Mol Med 2006, 84(I I):90I-9I0.

31. Protein Analysis THrough Evolutionary Relationships [http:/ /www.pantherdb.org]

32. Cluster 3.0 program [http://bonsai.ims.u-tokyo.ac.jp/ mdehoon/ software/cluster/software.htm]

33. BioMart [http://www.biomart.org]

34. National Center for Biotechnology Information [http:// www.ncbi.nlm.nih.gov]

35. UCSC genome browser [http://genome.ucsc.edu]

36. MySQL database management software www.mysql.com]

37. Heneweer $\mathrm{C}$, Kruse $\mathrm{LH}$, Kindhauser F, Schmidt M, Jakobs $\mathrm{KH}$, Denker HW, Thie M: Adhesiveness of human uterine epithelial RL95-2 cells to trophoblast: rho protein regulation. Mol Hum Reprod 2002, 8( I I): I014-1022.

38. Rahnama F, Thompson B, Steiner M, Shafiei F, Lobie PE, Mitchell MD: Epigenetic regulation of E-cadherin controls endometrial receptivity. Endocrinology 2009, I50(3): | 1466-1472.

39. Kininis $M$, Kraus WL: A global view of transcriptional regulation by nuclear receptors: gene expression, factor localization, and DNA sequence analysis. Nucl Recept Signal 2008, 6:e005.

40. Cowley SM, Hoare S, Mosselman S, Parker MG: Estrogen receptors alpha and beta form heterodimers on DNA. J Biol Chem 1997, 272(32): | 9858-19862.
4I. Lindberg MK, Moverare S, Skrtic S, Gao H, Dahlman-Wright K, Gustafsson JA, Ohlsson C: Estrogen receptor (ER)-beta reduces ERalpha-regulated gene transcription, supporting a "ying yang" relationship between ERalpha and ERbeta in mice. Mol Endocrinol 2003, I7(2):203-208.

42. Takamoto N, Zhao B, Tsai SY, DeMayo FJ: Identification of Indian hedgehog as a progesterone-responsive gene in the murine uterus. Mol Endocrinol 2002, 16(10):2338-2348.

43. Khatua A, Wang X, Ding T, Zhang Q, Reese J, DeMayo FJ, Paria BC Indian hedgehog, but not histidine decarboxylase or amphiregulin, is a progesterone-regulated uterine gene in hamsters. Endocrinology 2006, 147(9):4079-4092.

44. Lee K, Jeong J, Kwak I, Yu CT, Lanske B, Soegiarto DW, Toftgard R, Tsai MJ, Tsai S, Lydon JP, et al.: Indian hedgehog is a major mediator of progesterone signaling in the mouse uterus. Nat Genet 2006, 38( I 0): I 204-I 209

45. Simon L, Spiewak KA, Ekman GC, Kim J, Lydon JP, Bagchi MK, Bagchi IC, DeMayo FJ, Cooke PS: Stromal progesterone receptors mediate induction of Indian Hedgehog (IHH) in uterine epithelium and its downstream targets in uterine stroma. Endocrinology 2009, I 50(8):387|-3876.

46. Torchia J, Glass C, Rosenfeld MG: Co-activators and co-repressors in the integration of transcriptional responses. Curr Opin Cell Biol 1998, 10(3):373-383.

47. Khan OY, Nawaz Z: Nuclear hormone receptor co-regulators. Curr Opin Drug Discov Devel 2003, 6(5):692-70I.

48. Ellmann S, Sticht H, Thiel F, Beckmann MW, Strick R, Strissel PL: Estrogen and progesterone receptors: from molecular structures to clinical targets. Cell Mol Life Sci 2009, 66( I 5):2405-2426.

49. Losel R, Wehling M: Nongenomic actions of steroid hormones. Nat Rev Mol Cell Biol 2003, 4(I):46-56.

50. Kousteni S, Bellido T, Plotkin LI, O'Brien CA, Bodenner DL, Han L, Han K, DiGregorio GB, Katzenellenbogen JA, Katzenellenbogen BS, et al:: Nongenotropic, sex-nonspecific signaling through the estrogen or androgen receptors: dissociation from transcriptional activity. Cell 200I, I04(5):719-730.

\section{Publish with Bio Med Central and every scientist can read your work free of charge}

"BioMed Central will be the most significant development for disseminating the results of biomedical research in our lifetime. "

Sir Paul Nurse, Cancer Research UK

Your research papers will be:

- available free of charge to the entire biomedical community

- peer reviewed and published immediately upon acceptance

- cited in PubMed and archived on PubMed Central

- yours - you keep the copyright
BiolMedcentral 